\title{
KESIAPAN STASIUN TELEVISI LOKAL BATAM SEBAGAI MEDIA PENYEBARAN INFORMASI PUBLIK
}

\author{
Arifuddin \\ Balai Besar Pengkajian dan Pengembangan Komunikasi dan Informatika Medan \\ Jalan Tombak No.31 Medan (20222) Telp.061 6639817 Fax.061 6639816 HP. 081342570844 \\ e-mail: achmad_arifuddin@yahoo.com, arif012@kominfo.go.id \\ Naskah diterima tanggal 27 Februari 2015, direvisi tanggal 30 Juni 2015, disetujui tanggal 3 Juli 2015
}

\section{THE READINESS OF BATAM LOCAL TV STATION AS A MEDIUM OF PUBLIC INFORMATION DISSEMINATION}

\begin{abstract}
This research is related to the readiness of local TV stations in Batam as a media dissemination of public information in the border region in maintaining local identity of Batam, Riau (Kepri). This study is aimed to determine and identify the readiness of local TV Batam as media dissemination of public information in the border region in maintaining local identity. Study was conducted with qualitative research using case study method. The results of study indicated that four existing local TV stations in Batam, two of which, namely Batam TV and Urban TV expressed the readiness in hardware and software deployment as a dissemination medium for public information in maintaining the identity of the border region local and already using local content with sufficient volume in Network Station System (SSJ). While two other are Barelang TV and Penisula TV, is off the broadcast because the investment limitations and weak competitiveness against other local TV and national TV.
\end{abstract}

Keywords: readiness, local television, media dissemination of public information.

\begin{abstract}
Abstrak
Penelitian ini terkait tentang kesiapan stasiun TV lokal Batam sebagai media penyebaran informasi publik di wilayah perbatasan dalam memertahankan identitas lokal Batam Provinsi Riau (Kepri). Penelitian ini bertujuan untuk mengetahui dan mengidentifikasi kesiapan stasiun TV lokal Batam sebagai media penyebaran informasi publik di wilayah perbatasan dalam memertahankan identitas lokal. Penelitian ini menggunakan pendekatan kualitatif. Sedangkan metode penelitian menggunakan studi kasus. Hasil penelitian menunjukkan bahwa dari 4 (empat) stasiun TV lokal yang ada di Batam, dua di antaranya, yaitu Batam TV dan Urban TV menyatakan kesiapan baik dari segi perangkat keras maupun lunak sebagai media penyebaran informasi publik di wilayah perbatasan dalam memertahankan identitas lokal dan sudah menggunakan konten lokal sesuai volume penayangan program lokal dalam Sistem Stasiun Jaringan (SSJ). Sementara 2 (dua) lainnya yaitu Barelang TV dan Semenanjung TV, tidak aktif siaran karena keterbatasan investasi dan lemahnya daya saing terhadap TV lokal lainnya dan TV nasional.
\end{abstract}

Kata kunci: kesiapan, televisi lokal, media penyebaran informasi publik. 


\section{PENDAHULUAN}

Televisi merupakan media yang digunakan dalam proses komunikasi massa di mana penyelenggara siaran merupakan komunikator dan khalayak pemirsa adalah komunikan. Penggunaan televisi ini bermula dari penemuan seorang Jerman bernama Paul Nipkov pada tahun 1883-1884. Kemudian pada 1939 mulai dinikmati oleh publik Amerika, yaitu ketika berlangsungnya "World's Fair" di New York (Kuswandi dalam Anabarja 2011). Hingga saat ini televisi menjadi media yang paling banyak digunakan. Sebagai salah satu media massa yang digunakan dalam proses komunikasi, televisi memiliki kelebihan karena sifatnya yang langsung, tidak mengenal jarak dan memiliki daya tarik yang kuat.

Perkembangan dunia pertelevisian di Indonesia tidak lepas dari perkembangan media global yang akan membawa pengaruh yang tidak kecil terhadap media nasional suatu negara. Walaupun tidak dapat dipungkiri bahwa seringkali kiblat dari media global ini adalah negara-negara Barat yang menjadi pencetus pengembangan teknologi informasi dan komunikasi. Jika media global memiliki nilai dan pengaruh dari negara Barat yang dominan maka tak dapat dihindari pula pengaruhnya terhadap pemirsanya. Dengan semakin mudahnya nilai tersebut untuk masuk ke dalam masyarakat dunia termasuk masyarakat lokal di Indonesia, maka dirasakan pula oleh pemirsanya. Padahal, nilai-nilai dan ide merupakan suatu yang vital dalam pembentukan identitas suatu masyarakat. Dengan masuknya nilai-nilai Barat maka identitas lokal pun pasti akan terpengaruh. Hal inilah yang menjadi ancaman bagi eksistensi beragam bentuk kebiasaan, nilai, identitas dari budaya lokal. Sebagai masyarakat yang telah memiliki identitas sendiri dengan nilai-nilai tersendiri, tentunya hal di atas dapat dikatakan sebagai masalah. Karena dengan semakin masuknya nilai asing melalui globalisasi media, mau tidak mau akan pula meminggirkan nilai lokal hingga merubah identitas asli lokal (Anabarja, 2011)
Salah satunya adalah Kota Batam yang berdekatan dengan negara Singapura. Karena letaknya yang berdekatan, maka siaran televisi Singapura bisa tertangkap bersih di hampir seluruh wilayah Batam. Meskipun lebih dekat dengan Singapura, siaran televisi Malaysia juga bisa tertangkap bebas (free to air) di Batam. Saat ini di Batam bisa tertangkap siaran dari 14 stasiun televisi milik negara Singapura dan Malaysia. Dengan kondisi siaran televisi negara tetangga yang jumlahnya hampir sama dengan siaran televisi Indonesia, maka bagi masyarakat Batam siaran televisi asing sudah menjadi tontonan yang biasa. Ragam program yang ditayangkan siaran televisi negara tetangga juga banyak disukai masyarakat Batam. Selain memberi hiburan, ternyata ada juga ditemui program siaran televisi negara tetangga yang tidak sesuai dengan norma dan budaya Indonesia. Hal ini sering dijumpai pada program siaran yang ditayangkan oleh stasiun televisi Singapura. Misalnya batasan pornografi yang berbeda serta perbedaan waktu antara Indonesia dan Singapura, membuat anak-anak dapat menonton dengan bebas program untuk dewasa yang ditayangkan oleh siaran televisi Singapura. Padahal Pedoman Perilaku Penyiaran dan Standar Program Siaran (P3SPS) yang dibuat oleh Komisi Penyiaran Indonesia tentang peraturan mengenai penayangan sebuah program siaran, tidak berlaku di negara tetangga.

Kondisi penyiaran di Batam seperti yang diuraikan di atas sudah berlangsung sejak lama. Masyarakat Batam yang sejak kecil terbiasa menonton siaran Singapura dan Malaysia, menjadi butuh dengan siaran berbahasa Inggris, Mandarin, serta Melayu. Sedangkan bagi yang merasa butuh dengan informasi budaya, sejarah, dan berita tentang keluarganya yang berada di negara tetangga, merasa harus menyaksikan siaran televisi milik Singapura atau Malaysia setiap harinya.

Melihat keberagaman masyarakat Batam dalam menyikapi kehadiran siaran televisi Singapura dan Malaysia, dihadapkan pada kekhawatiran pemerintah akan terkikisnya rasa nasionalisme masyarakat di 
daerah perbatasan. Latar belakang etnis, motivasi, alasan pekerjaan dan pengalaman pribadi yang berhubungan dengan kedua negara tetangga menyebabkan tidak sedikit khalayak yang menjadikan siaran televisi Singapura dan Malaysia sebagai sumber informasi, hiburan, bahkan pendidikan (Desliana, 2012).

Menghadapi kenyataan di atas maka bermunculan bentuk-bentuk siaran regional atau beberapa televisi lokal yang memang mulai menunjukkan eksistensinya beberapa tahun belakangan ini. Dengan kemunculan stasiun televisi lokal tersebut maka dapat dikatakan bahwa hal ini merupakan salah satu bentuk usaha untuk menghasilkan budaya tandingan (counter culture) dari universalitas dalam berbagai performa informasi dan komunikasi media massa (Kuswandi dalam Anabarja 2011). Dengan mengusung nilainilai lokal pada tiap tayangannya, televisi lokal ini memiliki peran yang tidak kecil pada konstruksi identitas lokalnya. Ternyata sekarang hasilnya pun mulai tampak dengan semakin majunya televisi lokal dan peningkatan pemirsa televisi lokal. Mereka hadir dengan warna dan citarasa khas lokal pada upaya memertahankan identitas lokal dalam menghadapi realitas globalisasi media.

Dengan merujuk pada uraian di atas, maka permasalahan yang ingin dikaji dalam penelitian ini adalah "Bagaimana kesiapan stasiun televisi lokal Batam sebagai media penyebaran informasi publik di wilayah perbatasan dalam memertahankan identitas lokal". Adapun tujuan penelitian ini, adalah untuk mengetahui dan mengidentifikasi kesiapan stasiun televisi lokal Batam sebagai media penyebaran informasi publik di wilayah perbatasan dalam memertahankan identitas lokal. Sedangkan manfaat penelitian ini, adalah: 1) Bagi Kementerian Komunikasi dan Informatika terutama Balai Besar Pengkajian dan Pengembangan Komunikasi dan Informatika adalah sebagai penyediaan naskah berisi data dan informasi terolah mengenai peran stasiun televisi lokal Batam sebagai media penyebaran informasi publik di wilayah perbatasan Batam.

\section{LANDASAN KONSEP}

Denis McQuail menulis bahwa televisi yang pada mulanya dipandang sebagai barang mainan menjadi sebuah penemuan yang serius dan dapat memberikan sumbangan terhadap kehidupan sosial, sebagai alat pelayanan. Pada intinya, televisi hadir dengan memanfaatkan semua media yang telah ada sebelumnya (McQuail, 2000). Akibat dari perkembangan teknologi komunikasi massa televisi, maka akan memberikan pengaruh dalam banyak aspek kehidupan manusia. Pengaruh tersebut bisa dalam politik, ekonomi, sosial, budaya, bahkan pertahanan dan keamanan negara. Menurut Skornis, dibandingkan dengan media massa lainnya seperti radio, surat kabar, majalah, buku, dan sebagainya, televisi memunyai sifat istimewa. (Anabarja, 2011).

Undang-Undang No. 32 Pasal 14 ayat (3) tentang Lembaga Penyiaran Publik berbunyi "Di daerah provinsi atau kota di dirikan Lembaga Penyiaran Publik Lokal". Hal ini menunjukkan bahwa kehadiran televisi lokal memunyai kewajiban dan tanggung jawab untuk mengemas sebuah acara dan menyajikannya dengan mengutamakan permasalahan lokal atau daerah.

Televisi lokal memiliki positioning kuat sebagai media daerah. Mengapa dikatakan demikian? Karena televisi lokal di dalamnya memuat content (berita, musik, hiburan, program kesenian, kebudayaan, hingga potensi ekonomi lokal). Secara garis besar televisi lokal itu sesungguhnya menindikasikan 3 (tiga) kategori televisi yang berbeda, yaitu televisi komunitas, televisi komersial lokal dan televisi daerah (Sudibyo, 2004).

Pemanfaatan bahasa sebagai strategi penguatan identitas sesungguhnya merupakan hal yang sangat penting. Morrisan (2004) mengatakan kemasan bahasa dalam berita misalnya, sangat menentukan apakah penonton akan terus atau memindah saluran. Potensi stasiun televisi lokal beroperasi secara optimal cukup besar. Hal ini didukung amanat 
UU No. 32 Tahun 2002, Pasal 6 ayat (2) yang menyebutkan bahwa dalam sistem penyiaran nasional terdapat lembaga penyiaran dan pola jaringan yang adil dan terpadu yang dikembangkan dengan membentuk stasiun jaringan dan stasiun lokal. Dengan hadirnya televisi lokal dan televisi berjaringan, pemirsa tidak hanya dijejali informasi, budaya, dan gaya hidup global yang dihadirkan oleh televisi nasional. Pemirsa akan lebih banyak menyaksikan berbagai peristiwa dan dinamika di daerah dan lingkungannya. Oleh karena itu, televisi lokal merupakan kebutuhan masyarakat di daerah dalam proses menyeimbangkan informasi, termasuk untuk mengangkat kearifan lokal sebagai ciri yang kental dari masyarakat Indonesia. Walaupun memiliki potensi yang cukup besar, pada praktiknya perkembangan televisi lokal memiliki banyak kendala. Keterbatasan investasi dan lemahnya daya saing terhadap televisi nasional menjadi problem tersendiri bagi televisi lokal untuk bersaing dengan televisi nasional, hal ini kemudian mengakibatkan televisi lokal kesulitan di dalam mengembangkan dirinya. Popularitas televisi lokal di tengah masyarakat yang kalah jauh dibanding televisi nasional menjadi faktor bagi minimnya sponsor dan investasi pengiklan untuk ikut menghidupi televisi lokal. Masalah lain adalah pemerintah kurang tegas dalam merealisasikan UU Penyiaran No. 32 Tahun 2002 terkait kedudukan televisi lokal. Pelaksanaan pasal ini ditunda sampai tiga kali. Tahun 2005, 2007, baru ada bulan Desember tahun 2009 peraturan ini diberlakukan (Fardiah, 2012). Sementara itu dalam Pedoman Perilaku Penyiaran (P3) pasal 52 diatur tentang Volume Penayangan Program Lokal dalam Sistem Stasiun Jaringan (SSJ) sebagai berikut :

1. Program siaran lokal wajib diproduksi dan ditayangkan dengan durasi minimal $10 \%$ (sepuluh perseratus) dari total durasi siaran berjaringan per hari;

2. Program siaran lokal sebagaimana yang dimaksud pada ayat (1) minimal $30 \%$ (tiga puluh perseratus) diantaranya wajib ditayangkan pada waktu prime time waktu setempat;

3. Program siaran lokal sebagaimana yang dimaksud pada ayat (1) secara bertahap wajib ditingkatkan hingga 50\% (lima puluh per seratus) dari total durasi siaran berjaringan per hari.

Beberapa penelitian dan kajian tentang eksistensi televisi lokal sudah pernah dilakukan, salah satunya penelitian yang dilakukan pada tahun 2011 oleh Feriandi Mirza dengan judul "Eksistensi TV Lokal di Antara Dominasi TV Nasional" . Tujuan dari penelitian ini adalah untuk mengetahui sejauh mana eksistensi siaran dari stasiun-stasiun televisi lokal dibandingkan dengan stasiunstasiun televisi nasional. Hasil penelitian menyebutkan bahwa di tengah eksistensi televisi lokal yang seringkali dipertanyakan, saat ini muncul harapan dengan mulai dilaksanakannya Sistem Stasiun Jaringan (SSJ). Dengan diterapkannya SSJ, maka stasiun relay ibukota provinsi yang dimiliki stasiun televisi induk masih memungkinkan memiliki sahamnya sampai $90 \%$. Kesempatan itu berupa cakupan wilayah siaran yang sama dan kesempatan untuk menjadi anggota jaringan bagi stasiun televisi nasional berjaringan yang ingin memperluas jaringannya. Untuk daerah yang berpotensi ekonomi tinggi, bertarung secara langsung dengan televisi nasional berjaringan adalah pilihan yang menarik. Hal ini didasarkan pada fakta bahwa televisi lokal memiliki potensi yang sangat kuat untuk dijual. Program berita pun bisa menjadi nyata dengan lebih mendekatkan pemirsanya pada kejadiankejadian yang dekat dengan proximity, sehingga diharapkan dapat lebih menarik perhatian publik lokal sekaligus merebut pasar lokal. Sedangkan untuk daerah -daerah yang potensi ekonominya rendah, maka pilihan bekerjasama atau menjadi anggota jaringan dari televisi nasional adalah pilihan yang paling logis. Hal ini didasarkan pada fakta bahwa untuk bertarung secara langsung dengan televisi nasional dengan memroduksi program-program siaran yang berkualitas membutuhkan biaya yang tidak sedikit yang tidak sebanding dengan kekuatan modal 
pengelola televisi lokal. Hasil yang telah diperoleh dari penelitian tersebut di atas menunjukkan bahwa televisi lokal cukup berat memertahankan eksistensinya bersaing dengan televisi nasional.

Selain itu, Rinowati N.A juga melakukan penelitian dengan judul Eksistensi Televisi Lokal (Kasus: Eksistensi TVKU Dalam Kompetisi Industri Penyiaran, Tahun 2012). Penelitian ini dilakukan dengan tujuan untuk mengetahui bagaimana eksistensi televisi lokal, dengan studi kasus pada TVKU sebagai televisi lokal yang memiliki diferensiasi sebagai televisi lokal pendidikan. Metode studi kasus digunakan agar didapatkan gambaran mendalam mengenai kondisi TVKU sebagai entitas bisnis, sekaligus upaya-upaya yang dilakukan untuk memertahankan eksistensi. Hasil penelitian menunjukkan bahwa sebagai televisi lokal komersial, TVKU masih merasakan beratnya persaingan/kompetisi dalam industri penyiaran televisi. Sebagai entitas bisnis, TVKU masih dalam kondisi merugi. Hal ini disebabkan karena sulitnya akses iklan yang masih terpusat di Jakarta. Untuk memertahankan eksistensi dan memerbaiki kondisinya.

Adapun konsep dasar dari kesiapan televisi lokal Batam sebagai media penyebaran informasi publik di wilayah perbatasan dalam memertahankan identitas lokal yaitu kesiapan perangkat keras maupun perangkat lunak yang dimiliki untuk memroduksi siaran sesuai yang ditetapkan. Perangkat keras terkait dengan sarana dan prasarana yang berhubungan dengan peralatan teknis sebuah stasiun televisi antara lain menyangkut operasional transmitter, ruang kontrol, kamera, videotape recorder, film dan slide projector, dan sebagainya. Sedangkan yang terkait dengan perangkat lunak yakni di dalamnya mencakup pengelolaan program dan network, content/ berita/siaran (pada pemenuhan informasi publik, termasuk potensi ekonomi lokal), musik/hiburan, kebudayaan, hingga pada pengelolaan finansial, dan sumber daya manusia (SDM).
Dalam kesiapan lembaga penyiaran televisi lokal Batam sebagai media penyebaran informasi publik di wilayah perbatasan Kepulauan Riau, akan dilihat dari 2 (dua) aspek. Aspek pertama adalah kesiapan lembaga penyiaran televisi lokal Batam dalam mengimplementasikan UU Penyiaran No. 32 Tahun 2002, terutama tentang kedudukan televisi lokal Batam, yakni di mulai dari segi input, proses, dan output, yang dirinci ke dalam beberapa indikator, yaitu: (a) Respon lembaga penyiaran televisi lokal Batam tentang kedudukan televisi lokal; (b) Kebijakan lembaga penyiaran televisi lokal Batam dalam mempersiapkan layanan informasi public; (c) Kesiapan perangkat keras/ lunak untuk sarana dan prasarana pelayanan informasi public; (e) Kesiapan sumber daya manusia (SDM) yang paham mengenai UU Penyiaran No. 32 Tahun 2002, terutama tentang kedudukan televisi lokal; (f) Pendidikan/ diklat tertentu untuk untuk penyiapan SDM layanan informasi publik; (g) Mekanisme/ sistem pelayanan informasi publik yang diberlakukan pada lembaga penyiaran televisi lokal; (h) Anggaran khusus untuk mendukung operasional penyebaran informasi publik di wilayah perbatasan. Aspek kedua adalah hambatan atau sebagai kendala faktor dominan yang menjadi hambatan lembaga penyiaran televisi lokal Batam dalam memberikan layanan informasi publik ke wilayah perbatasan atau sebagai media penyebaran informasi publik di wilayah perbatasan. Kemudian saran-saran yang diinginkan pengelola lembaga penyiaran televisi lokal terkait implementasi kedudukan lembaga penyiaran televisi lokal dalam UU Penyiaran No 32 Tahun 2002.

Konsep dasar dari kesiapan televisi lokal Batam sebagai media penyebaran informasi publik di wilayah perbatasan dalam memertahankan identitas lokal, yaitu adanya kesiapan pengetahuan (penyiaran yang disebut broadcasting), sikap (attitude), dan perilaku (behaviour). Dengan kata lain kesiapan televisi lokal Batam sebagai media penyebaran informasi publik di wilayah perbatasan tidak lepas dari adanya 
pengetahuan, sikap, dan perilaku yang dimiliki baik individu maupun kolektif tentang penyiaran atau broadcasting itu sendiri. Pengetahuan yang dimaksudkan dalam kajian ini adalah kesiapan pengetahuan penyiaran atau broadcasting.

Menurut Undang-Undang No. 32 Tahun 2002, penyiaran disebut broadcasting memiliki pengertian sebagai kegiatan pemancarluasan siaran melalui sarana pemancaran dan/atau sarana transmisi di darat, di laut, dan di antariksa dengan menggunakan spektrum frekuensi radio (sinyal radio) yang berbentuk gelombang elektromagnetik yang merambat melalui udara, kabel, dan/atau media lainnya untuk dapat diterima secara serentak dan bersamaan oleh masyarakat dengan perangkat penerima siaran.

Broadcasting merupakan sub disiplin
ilmu komunikasi terapan (applied communication) yang khusus memelajari pengemasan pesan melalui media massa elektronik seperti televisi, radio, dan internet. Dalam broadcasting juga memperdalam ilmu kemasyarakatan, artinya bagaimana cara seseorang terjun langsung dan berhadapan dengan masyarakat luas. Ruang lingkup broadcast meliputi:

1. Presenter

2. Kameramen

3. Wartawan media

4. Dunia perfilman, seperti: sutradara, produser, editor, dan lain-lain.

Tidak kalah pentingnya adalah kesiapan televisi lokal Batam sebagai sebuah sarana atau medium atau perangkat yang mutlak dipergunakan dalam kehidupan masyarakat sehari-hari, khususnya sebagai media penyebaran informasi publik di wilayah perbatasan dan sebagai sebagai sebuah inovasi memerlukan sikap positif. Apakah inovasi tersebut memberi keuntungan bagi pribadi tertentu dan sesuai dengan harapanharapannya di masa depan? Apakah inovasi sudah pernah dicoba sehinggga memberi kepercayaan pada dirinya? Atau objek inovasi tersebut tidak terlalu rumit sehingga tidak menimbulkan risiko-risiko yang kompleks di waktu yang akan datang (Bungin, 2006).
Rangkaian selanjutnya yang juga sangat menentukan kesiapan televisi lokal Batam sebagai media penyebaran informasi publik di wilayah perbatasan Kepulauan Riau yaitu faktor perilaku. Perilaku adalah suatu kegiatan dan aktivitas organisme yang bersangkutan, baik aktivitas yang dapat diamati atau yang tidak dapat diamati oleh orang lain. Manusia berperilaku atau beraktivitas karena adanya kebutuhan untuk mencapai suatu tujuan/goal. Dengan adanya kebutuhan akan muncul motivasi atau penggerak. Sehingga individu itu akan beraktivitas untuk mencapai tujuan dan mengalami kepuasan.

\section{METODE PENELITIAN}

Penelitian ini menggunakan pendekatan kualitatif, sedangkan metode penelitian menggunakan studi kasus. Dalam hal penelitian kualitatif. Studi kasus merupakan salah satu jenis penelitian kualitatif, di mana peneliti melakukan eksplorasi secara mendalam terhadap program, kejadian, proses, aktivitas, terhadap satu atau lebih orang.

Metode penelitian kualitatif dilakukan secara intensif, peneliti ikut berpartisipasi lama di lapangan, mencatat secara hati-hati apa yang terjadi, melakukan analisis reflektif terhadap berbagai dokumen yang ditemukan di lapangan, dan membuat laporan penelitian secara mendetail.

Studi kasus sebagai metode penelitian merupakan bentuk penelitian yang mendalam tentang suatu aspek lingkungan sosial yang mana manusia termasuk di dalamnya (Nasution, 2006). Defenisi ini masih dianggap umum. Lebih spesifik dikemukakan Robert K. Yin (2003) memberi batasan studi kasus sebagai suatu penelitian empiris yang menyelidiki fenomena dalam konteks kehidupan nyata, bilamana batas-batas antara fenomena dengan konteks tidak tampak dengan tegas; dan di mana multi sumber bukti digunakan. 
Penelitian ini dilaksanakan di Batam Provinsi Riau. Fokus pengumpulan datanya pada televisi lokal Batam, yaitu Batam TV, Semenanjung TV, Urban TV, dan Barelang TV. Jadwal pelaksanaan penelitian ini dilaksanakan pada bulan Maret s/d Agustus 2014.

Informan dalam penelitian ini adalah (1) Pengelola media penyiaran televisi lokal Batam, yaitu Batam TV dan Urban TV Batam; (2) Komisi Penyiaran Informasi Daerah (KPID) Batam; (3) Balai Monitor Spektrum Frekuensi Radio dan Orbit Satelit Kelas II Batam; (4) Badan Komunikasi dan Informatika Kota Batam. Adapun lokasi penelitian ini adalah di Kota Batam. Guna memeroleh data yang diperlukan dalam penelitian ini, pengumpulan datanya menggunakan 3 (tiga) teknik, yaitu: (1) teknik observasi, (2) teknik wawancara mendalam, (3) studi dokumentasi.

Teknik pengumpulan data dengan dokumen. Dokumen bisa berbentuk tulisan, gambar, atau karya-karya monumental dari seseorang (Sugiyono 2013). Sedangkan teknik analisis data yang digunakan dalam penelitian ini yakni melalui pendekatan kualitatif. Data diperoleh dari berbagai sumber dengan menggunakan teknik pengumpulan data, Miles dan Huberman dalam Sugiyono (2013) mengemukakan bahwa aktivitas dalam analisis data kualitatif dilakukan secara interaktif dan berlangsung secara terus menerus sampai tuntas, sehingga datanya sudah jenuh. Aktivitas dalam analisis data, yaitu: (a) data reduction (reduksi data), (b) data display (penyajian data), dan (c) conclusion drawing/ verification (penarikan kesimpulan dan verifikasi).

\section{HASIL PENELITIAN DAN PEMBAHASAN}

Terkait kesiapan televisi lokal Batam sebagai media penyebaran informasi publik di wilayah perbatasan dalam mempertahankan identitas lokal Batam Provinsi Riau (Kepri), dapat dilihat dari kesiapan perangkat keras dan lunak. Namun, sebelum hal ini dibahas perlu dikemukakan bahwa seusai hasil pengumpulan data di lapangan menunjukkan bahwa dari 4 (empat) televisi lokal yang ada di Kota Batam, yaitu: (1) PT. Batam Multimedia Televisi (Batam TV), (2) PT. Semenanjung Televisi (STV), (3) PT. Urban Televisi (UTV), dan (4) PT. Duta Batam Televisindo (Barelang TV). Dari ke empat televisi lokal tersebut, hanya 2 (dua) diantaranya yang aktif bersiaran yakni PT. Batam Multimedia Televisi (Batam TV) dan Urban Televisi (UTV). Sementara 2 (dua) lainnya yakni PT. Semenanjung Televisi (STV) dan PT. Duta Batam Televisindo (Barelang TV) tidak aktif bersiaran.

Hasil wawancara dengan Komisioner Komisi Penyiaran Informasi Daerah (KPID) Kepulauan Riau Bidang Komunikasi dan Teknologi Batam, H. Moch. Aminuddin Hadi, S.E., S.Sos., MM mengatakan keterbatasan investasi dan lemahnya daya saing terhadap televisi nasional maupun televisi lokal lainnya di Kepulauan Riau ini, khususnya di Batam menjadi kendala tersendiri bagi kedua televisi lokal tersebut untuk bersaing dengan televisi lokal lainnya. Hal ini kemudian mengakibatkan televisi lokal Semenanjung TV dan Barelang TV kesulitan di dalam mengembangkan dirinya, sehingga kedua televisi lokal tersebut inkonsisten dalam bersiaran (Hasil wawancara, 24/05/2014).

Adapun kesiapan televisi lokal Batam sebagai media penyebaran informasi publik di wilayah perbatasan dalam memertahankan identitas lokal Batam Provinsi Riau (Kepri), seperti dikemukakan terdahulu dapat dilihat dari segi perangkat keras dan lunak yang dimiliki televisi lokal Batam TV maupun Urban TV, maka sesuai hasil temuan di lapangan menunjukkan bahwa untuk Batam TV seperti yang dikemukakan Bachtian (General Manager Batam TV) menyatakan Batam TV yang mengundara di Frekuensi 51 UHF saat ini memiliki daya pancar 5 kilo watt (5.000watt). Dengan kekuatan pancar sebesar ini, maka coverage area Batam TV sudah dapat diterima di Kota Batam (800.000 jiwa), Tanjungpinang (300.000 jiwa), Bintan 
(200.000 jiwa), Tanjunguban dan Lobam (150.000 jiwa), Karimun (250.000) jiwa, Singapura (2.000.000 jiwa), dan Johor Bahru Malaysia (500.000 jiwa).

Menurut Bachtiar, saat ini Batam TV masih menggunakan perangkat teknologi standar untuk mengelola program siaran yang dominan adalah berita. Jangkauan siar Batam TV sudah mencakup seluruh area Kepulauan Riau (Kepri), Singapura hingga Johor Bahru Malaysia. Stasiun televisi ini merupakan anggota jaringan Jawa Pos Multimedia Corporation (JPMC). Kekuatan daya pancar saat ini adalah $5 \mathrm{KW}$ dipancarkan di Channel 51 UHF dan terus melakukan pengembangan untuk semakin memperluas jangkauan siarnya. Jam siaran saat ini sudah dilakukan sejak pukul 07.00-24.00 WIB dengan beragam mata acara unggulan, yang terdiri dari program berita, Lejel Home Shopping program hiburan, program anak-anak, program keagamaan, program kesehatan dan lain-lain. Khusus program berita didapatkan dari beberapa daerah di Kepulauan Riau seperti: Batam, Karimun, Tanjungpinang, Lingga, Bintan dan Natuna. Berita-berita yang ditayangkan lebih menitikberatkan berita-berita lokal. Studio operasional dilakukan dari lantai 9 Gedung Graha Pena, Jalan Raya Batam Centre Pulau Batam.

Lebih lanjut Bachtiar General Manager Batam TV, mengatakan bahwa sejalan dengan perkembangan Kota Batam dan pertumbuhan ekonomi sebesar 5,5\%, maka dengan perkembangan tersebut Batam TV memiliki sejumlah program yang dikhususkan untuk memenuhi kebutuhan penduduk Kepulauan Riau sudah disiapkan sesuai dengan tuntunan Broadcast. Batam TV juga memiliki tenaga-tenaga cukup profesional yakni sebanyak 65 orang, termasuk kameramen yang tersebar di Kepulauan Riau yaitu di Batam, Karimun, Tanjungpinang, Lingga, Bintan dan Natuna. Diantaranya juga terdapat wartawan yang sudah berkecimpung di dunia media cetak hingga 5 tahun. Selain itu semua tenaga sudah mengikuti pendidikan broadcast dari televisi nasional selama 1 bulan dan pelatihan dari
Padjadjaran Televisi disingkat PJTV (Hasil wawancara, 22/05/2014).

Terkait mekanisme sistem pelayanan informasi publik, Bachtiar mengatakan Batam TV bekerjasama dengan beberapa instansi di Batam untuk membahas topik-topik tertentu, misalnya kasus trafficking dan HIV/AIDS, bekerjasama dengan Dinas Kesehatan untuk menyosialisasikan kepada publik untuk kasus tersebut. Selain itu menurut Bachtiar bahwa Batam TV sebagai televisi lokal di Kepulauan Riau khususnya Kota Batam, memfokuskan diri terhadap minat dan keinginan pemirsa di Bumi Melayu Provinsi Kepulauan Riau. Jika televisi nasional memberikan program yang bersifat umum dan universal, maka Batam TV lebih menekankan program yang bernuansa lokal yang melibatkan pemirsa melalui program interaktif via telepon, SMS, dan melakukan kegiatan off air untuk memperkuat penetrasi ke masyarakat.

Dengan beberapa dasar tersebut maka Batam TV membuat program yang betulbetul dekat dengan masyarakat dan melibatkan masyarakat sebagai peserta dalam setiap program acara Batam TV. Hasil studi dokumentasi tentang paket siaran/program acara Batam TV, antara lain dapat dikemukakan: (1) Detak Kepri adalah berisikan berbagai informasi yang terjadi di Batam, Tanjungpinang, Tanjung Balai Karimun, dan Bintan. Berita di Batam news merupakan berita tercepat, akurat, dan terlengkap terhadap berbagai kejadian di Batam, Tanjungpinang, Karimun, dan Bintan; (2) Info Malam adalah berisikan infomasi terbaru termasuk peristiwa yang terjadi dari pukul 18.00-22.00 reporter melaporkan kejadian tersebut langsung dari lapangan; (3) Sweeping adalah berita-berita kriminal dalam sepekan yang terjadi di Batam Tanjungpinang, Tanjung Balai Karimun, dan Bintan, dan seterusnya masih banyak program lainnya (Sumber data : PT. Batam Multimedia Televisi/Batam TV- 22/05/2014).

Hal yang sama juga dikemukakan Imam Subari (Head Master Producer- Urban TV (UTV), mengenai kesiapan Urban TV sebagai televisi lokal Batam , baik dari segi perangkat keras maupun lunak, antara lain mengatakan 
bahwa UTV atau Urban TV Batam adalah salah satu televisi lokal berjaringan SINDO TV dan MNC Group mengudara dan dapat disaksikan lewat channel 61 UHF yang menjangkau daerah di provinsi Kepulauan Riau yakni Kota Batam, Kota Tanjungpinang, Kabupaten Bintan dan Kabupaten Karimun (Hasil wawancara, 23/05/2014).

Terkait kesiapan perangkat keras maupun perangkat lunak Urban TV, Imam Subari mengatakan cukup siap untuk memroduksi program siaran lokal, termasuk sumber daya manusia (SDM) yang jumlahnya sebanyak 15 crew ditambah dengan tenagatenaga freelance yang jumlah sebanyak 8 orang, termasuk kameramen yang nota bene cukup berkualitas karena senantiasa kami lakukan training kepada crew /staf UTV dengan standar berkualifikasi untuk memrogram siaran lebih baik (Hasil wawancara, 23/05/2014).

Menurut Imam Subari Stasiun televisi ini berdiri sejak tahun 2011 di Kota Batam. URBAN TV mengudara selama 18 jam dari pukul 06:00 hingga pukul 00:00 pagi, dengan konten lokal selama 4 jam. Tayangan konten lokal URBAN TV mencangkup 60\% news lokal Kepulauan Riau dan 40\% Non News (Musik daerah, Budaya Lokal dan Religi ). Eksistensi Urban TV di tengah masyarakat Batam dan sekitarnya diharapkan mampu menjadi media komunikasi yang efektif dalam mendukung pembangunan di Kepulauan Riau khususnya di Batam.

Imam Subari juga mengatakan selama 2 (dua) tahun Urban TV bersiaran di channel 61 di Batam secara intens menyajikan konten lokal paling tidak 3 - 4 jam perhari dari total siaran 18 jam. Dari segi materi untuk program-program konten lokalnya kita harapkan bisa mendidik dan mencerdaskan masyarakat sebagaimana diamanatkan dalam UU Penyiaran No. 32 Tahun 2002, khususnya mengenai kedudukan televisi lokal dalam UU tersebut. Namun disadari juga banyaknya masalah yang dihadapi oleh industri televisi lokal menuntut perhatian dan upaya untuk mengatasinya. Hal ini bukan hanya menjadi tanggung jawab regulator penyiaran, melainkan juga menjadi tanggung jawab pengelola televisi lokal itu sendiri. Dari sudut regulator diharapkan ada regulasi atau kebijakan yang memihak terhadap tumbuh kembangnya televisi lokal. Dukungan biaya operasional yang cukup dan stabil dari pemilik sangat menentukan kemampuan suatu stasiun televisi lokal untuk memproduksi dan menyiarkan program bermutu, menarik, diminati dan dibutuhkan masyarakat.

Mengenai upaya Urban TV dalam menyiasati siaran-siaran dari luar yakni Malaysia dan Singapura (TV1,TV2, TV3 dan seterusnya) Imam Subari mengatakan paling tidak pengelola produksi siaran merasa bertanggung jawab menawarkan programprogram yang kita buat menarik untuk bisa bersaing dengan televisi asing/ televisi negara tetangga, sehingga masyarakat/ pemirsa tidak berpaling ke siaran-siaran televisi asing tersebut, antara lain seperti program-program yang sifatnya informatif dan inovatif berupa Seputar Kepulauan Riau (Kepri) yang mengupas tentang beragam berita, peristiwa yang berada di Kepri yang dapat disaksikan di seputar Kepri yang khusus disajikan Urban TV kepada warga kota Batam. Kemudian juga dalam dunia entertainment, selain menyajikan program musik, Urban TV juga menyajikan program acara komedi lokal khas Kepri (Hasil wawancara, 23/05/2014).

Senada dengan yang dikemukakan $\mathrm{H}$. Moch. Aminuddin Hadi, Komisioner Komisi Penyiaran Informasi Daerah (KPID) Kepulauan Riau Bidang Komunikasi dan Teknologi Batam, bahwa dari sisi produksi baik Batam TV maupun Urban TV itu adalah stasiun televisi yang selama ini kami sebut sebagai televisi yang sudah layak dalam bersiaran, artinya mereka mampu memproduksi, ada liputan kemampuan produksi, ada kemampuan menyiarkan secara konsisten dan sudah menggunakan konten lokal sesuai volume penayangan program lokal dalam Sistem Stasiun Jaringan (SSJ) yang pada intinya menegaskan bahwa televisi lokal itu wajib hukumnya menyiarkan program siaran lokal sesuai Pedoman Perilaku Penyiaran (P3) yang wajib diproduksi dan ditayangkan dengan durasi 
minmal 10\% (sepuluh persen), kemudian $30 \%$ (tiga puluh persen) wajib ditayangkan pada waktu prime time waktu setempat, dan secara bertahap wajib ditingkatkan hingga $50 \%$ (lima puluh per seratus) dari total durasi siaran berjaringan per hari. Sementara televisi lokal Semenanjung TV dan Barelang TV belum konsisten dalam program siaran sebagai televisi lokal tersebut (Hasil wawancara, tanggal 24/05/2014).

Bahkan menurut Aminuddin Hadi, masyarakat Batam sudah sangat akrab dengan kedua TV tersebut yaitu Batam TV dan Urban TV. Menanggapi soal siaran-siaran dari luar negeri, terutama Malaysia dan Singapura, menurut Aminuddin Hadi, siaran luar negeri tersebut memiliki kemampuan yang kuat sehingga sangat memungkinkan program siaran TV luar negeri tersebut dapat ditonton di Kota Batam, apalagi pada daerah perbatasan yang kategori blankspot seperti Tanjung Balai Karimun yang berbatasan langsung dengan Malaysia. Disana tidak ada siaran televisi nasional yang masuk, tapi justru televisi asing. Sudah tentu masyarakatnya lebih mengenal lagu kebangsaan Singapura dan Malaysia, dan bahkan bahasa sangat dipengaruhi oleh bahasa Melayu Malaysia. Untuk itu menurut H. Moch.Aminuddin Hadi, perlu dipercepat digitalisasi siaran di daerah perbatasan dan kepulauan agar dapat terjangkau informasi, karena sudah kewajiban pemerintah untuk menyampaikan informasi itu ke publik (Hasil wawancara, tanggal 24/05/2014).

Hasil studi dokumentasi siaran/ program acara Urban TV adalah sesuai Visi dan Misi Urban TV. Adapun visinya adalah menjadi information center yang menghibur, bertradisi, bersama dalam etnis bagi pembangunan Batam. Sedangkan misinya adalah:

- Mengelola program televisi yang informatif, menghibur, berpendidikan, dan mampu mencitrakan kemampuan daerah dengan baik demi pembangunan;

- Menjalankan produksi dengan dukungan sarana dan prasarana yang layak dengan memanfaatkan kemajuan teknologi serta senantiasa sesuai dengan perkembangan jaman;

- Mengelola pendapatan perusahaan dengan motivasi untuk kemajuan perusahaan;

- Menjalankan usaha dengan manajemen sebaik-baiknya untuk kemajuan perusahaan;

- Memberikan manfaat dan kesempatan meningkatkan kesejahteraan kepada stakeholder Urban TV Batam hadir dengan motto: "Media Pemersatu Multi Ethnis untuk Pembangunan Batam"

Berdasarkan Visi dan Misi Urban TV diatas, maka produk/ program acara Urban TV adalah produk atau produksi yang dihasilkan oleh Urban TV Batam dengan konten lokal adalah sangat beraneka ragam mulai dari News, Religi, Feature, Entertainment Sport, dan Informasi. Berbagai produk tersebut diproduksi dengan baik sehingga menghasilkan program yang inovatif dan informatif, yaitu news. Beberapa produksi yang dihasilkan oleh Urban TV dengan genre news adalah:(1) Seputar Kepulauan Riau (Kepri) yaitu beragam berita, peristiwa yang berada di Kepri dapat disaksikan di seputar Kepri yang khusus disajikan UTV kepada warga kota Batam, (2) Ringkus adalah liputan atau berita-berita kriminal yang sedang terjadi di Kepri, dan (3) Bincang Santai yaitu dialog atau percakapan santai antara host dengan narasumber mengenai berita atau isu yang sedang hangat di Kepri, dan seterusnya masih banyak lagi program acara lainnya. (Sumber data PT. Urban Televisi (UTV- 23/05/2014).

Adapun kendala utama yang dihadapi Batam TV dalam kegiatan operasional termasuk didalamnya untuk penyebaran informasi publik ke masyarakat, menurut Bachtian (General Manager Batam TV) adalah SDM, karena hampir semua crew yang ada sangat minim yang berkualifikasi penyiaran televisi. Karena itu menurut Bachtian harus mengikuti pendidikan broadcasting dan pelatihan dari Padjadjaran Televisi disingkat PJTV. Terakhir saran dikemukakan Bachtian adalah terkait peraturan yang dibuat Kementerian 
Komunikasi dan Informatika selalu berubahubah. Karena itu perlu ada aturan yang jelas dan konsistensi mengenai eksistensi televisi lokal di daerah (Hasil wawancara, 22/05/2014).

Sementara itu, menurut Imam Subari (Head Master Producer- Urban TV) mengatakan bahwa secara teknis tidak ada kendala yang dirasakan untuk pengelolaan program siaran. Namun yang paling pokok yaitu bagaimana menjamin kelangsungan hidup industri televisi lokal dalam konteks persaingan bisnis media. Persaingan ini tidak bisa dihindari, karena televisi lokal ini akan nimbrung dalam perebutan kue iklan yang selama ini diperebutkan oleh media cetak, radio, dan televisi. Terakhir saran yang dikemukakan Iman Subari adalah pemerintah provinsi harus turut memikirkan langkahlangkah ke depan yang harus dilakukan oleh stasiun televisi lokal di daerahnya. Sebab, sekali lagi, dengan hidup dan berkembangnya stasiun televisi lokal di daerah secara mapan, secara tidak langsung iklim investasi di daerah pun akan turut berkembang (Hasil wawancara, 23/05/2014).

Terkait hambatan-hambatan yang dialami televisi lokal Batam dalam pelaksanaan kegiatan operasionalnya seperti yang dikeluhkan oleh beberapa televisi lokal di Batam, menurut $\mathrm{H}$. Moch Aminuddin Hadi, kendalanya adalah seperti pembiayaan untuk mendapatkan iklan sangat terbatas dan sangat minim. Dan mereka (televisi lokal Batam) menganggap pemerintah masih senang membelanjakan biaya publikasi itu malalui media cetak dibanding melalui media televisi lokal dan radio. Karena itu mereka (televisi lokal Batam) meminta kepada Komisi Penyiaran Indonesia Daerah (KPID) Kepulauan Riau (Kepri) agar menyampaikan hal ini kepada pemerintah provinsi, kabupaten/kota, supaya kegiatan-kegiatan yang sifatnya sosialisasi dan publikasi kebijakan baik pemerintah pusat maupun daerah sebaiknya adalah melalui televisi dan radio lokal karena jangkauannya jauh lebih luas.

Terakhir saran yang dikemukakan $\mathrm{H}$. Moch. Aminuddin Hadi, SE.S.Sos, MM -
Komisioner KPID Kepri Bidang Komunikasi dan Teknologi Batam, bahwa untuk kelangsungan hidup televisi lokal di Batam, sebaiknya Kementerian Komunikasi dan Informatika (Kominfo) membuat peraturan yang juga benar-benar pro dengan stasiun televisi lokal yang ada di daerah, termasuk di Batam. Regulasi Sistem Stasiun Jaringan (SSJ) perlu di tinjau ulang, sehingga benarbenar bisa memberi peluang televisi lokal untuk hidup dan berkembang (Hasil wawancara, tanggal 24/05/2014).

\section{PENUTUP}

\section{Simpulan}

Kesiapan televisi lokal Batam sebagai media penyebaran informasi publik di wilayah perbatasan dalam memertahankan identitas lokal dapat dilihat dari segi perangkat keras dan lunak. Dari segi perangkat keras kedua TV tersebut (Batam TV dan UrbanTV) sudah layak bersiaran, karena kedua TV tersebut mampu memroduksi program siaran; ada liputan kemampuan produksi, ada kemampuan menyiarkan secara konsisten dan sudah menggunakan konten lokal sesuai volume penayangan program lokal dalam Sistem Stasiun Jaringan (SSJ). Sedangkan Barelang TV maupun Semenanjung TV tidak aktif siaran karena keterbatasan investasi.

Kehadiran media penyiaran televisi lokal di Batam selain menghadapi kendala finansial dan sumber daya manusia, ditambah pula dengan belum adanya atau tidak adanya Perda yang secara eksplisit menyokong tentang tumbuhkembangnya televisi lokal di Batam, sehingga secara tidak langsung berdampak pada perkembangan televisi lokal terutama dalam mengusung kepentingan publik yang berbasis kearifan lokal secara maksimal.

\section{Saran}

Banyaknya masalah yang dihadapi oleh industri televisi lokal di Batam menuntut perhatian dan upaya untuk mengatasinya. 
Dari sudut regulator diharapkan ada regulasi atau kebijakan yang benar-benar memihak terhadap tumbuh kembangnya televisi lokal di Batam. Regulasi Sistem Stasiun Jaringan (SSJ), benar-benar bisa memberi peluang televisi lokal di Batam untuk hidup dan berkembang.

Pemerintah Provinsi Kepulauan Riau perlu memikirkan langkah-langkah ke depan apa yang harus dilakukan oleh stasiun televisi lokal di daerahnya. Sebab hidup dan berkembangnya stasiun televisi lokal terutama secara mapan, terutama di Batam, secara tidak langsung iklim investasi di daerah pun akan turut berkembang.

\section{DAFTAR PUSTAKA}

\section{Buku:}

Bungin, Burhan. (2006). Teknik Praktis Riset Komunikasi. Jakarta: Kencana Prenada Media Group.

Morissan. (2004). Jurnalistik Televisi Mutakhir. Jakarta: Penerbit Ghalia Indonesia.

McQuail, Dennis. (2000). Mass Communication Theories. Sage Publication.

Nasution. (2004). Komunikasi Pembangunan. Jakarta: PT. Raja Grafindo Persada.

Nasution. (2006). Metode Research (Penelitian Ilmiah). Jakarta: Bumi Aksara.

Sudibyo, Agus. 2004. Ekonomi Politik Media Penyiaran, LKIS Yogyakarta.

Sugiyono. (2013). Metode Penelitian Manajemen. Bandung: Alfabeta.

Yin, Robert K. (2003). Studi Kasus: Disain dan Metode. Jakarta: PT. Raja Grafindo Persada.

\section{Jurnal:}

Anabarja, Sarah. (2011). Peran Televisi Lokal Dalam Mempertahankan Identitas Lokal Era Globalisasi. Media Jurnal Global dan Strategis [internet],
Desember, 5 (3) hal. 263-264. Tersedia dalam: <http://journal.unair.ac.id> [diakses 9 Mei 2014].

Desliana, Dwita. (2012). Resepsi Masyarakat Terhadap Siaran Televisi Asing. Jurnal Semai Komunikasi, 2Juni, hal 136. [internet]. Tersedia dalam http://www.ejurnal.com/2014/05/resepsi-masyarakatterhadap-siaran.html. diakses 9 Mei 2014.

Fardiah, Dedeh. (2012). Peluang Dan Tantangan Membangun Media Penyiaran Berbasis Kearifan Lokal Di Jawa Barat. Dalam Prodising Seminar Nasional Menggagas Pencitraan Berbasis Kearifan Lokal,ed.Toto Sugito, dkk hal. 218 Tersedia dalam: < http://untar.ac.id/fikom/wpcontent/uploads/2015/05/ProsidingSeminar-Nasional-MenggagasPencitraan-Berbasis-..1.pdf > [Diakses 9 Mei 2014].

Mirza, Feriandi. (2011). Eksistensi TV Lokal di Antara Dominasi TV Nasional. Tersedia dalam

http://www.slideshare.net/efmirza/eksis tensi-tv-lokal-di-antara-dominasi-tvnasional, diakses 9 Mei 2014.

N.A. Rinowati. (2012). Eksistensi Televisi Lokal (Kasus: Eksistensi TVKU Dalam Kompetensi Industri Penyiaran) [internet]. Tersedia dalam: <core.kmi.open.ac.uk/dowload/pdf/117 35550.pdf.> [Diakses 10 Mei 2014].

Nugroho, Tri. (2009). Strategi Mengemas Identitas Lokal dalam Mengembangkan Televisi Lokal [internet]. Tersedia dalam:

<http://www.komuniasi.unsoed.ac.id > [diakses 9 Mei 2014].

\section{Perundang-undangan:}

Undang-Undang Penyiaran No. 32 Tahun 2002.

Pedoman Perilaku Penyiaran (P3) dan Standar Program Penyiaran (SPP) Tahun 2012. 